\title{
КРЫСТЫНа РАтайчИК
}

Лодзинский университет, Филологический факультет, Институт русистики, Кафедра языкознания (Лодзь, Польша)

\section{Контаминированные прецедентные тексты в газетных заголовках - как один из признаков современного публицистического стиля (семантика и прагматика)}

Газетный заголовок - это неотъемлемая часть публицистического текста1. Это «текст о тексте» (Михейкина 2013: 79), «аббревиатура смысла», «ярлык» (Аулова 2008: 160), «собственное имя текста» (Аулова 2008: 160, см. также Gajda 1987), «компас, ориентирующий читателя на газетной полосе» (Свистельникова 2008: 167). Заголовок выполняет в газетном тексте важнейшую коммуникативную функцию, информирует о содержании газетной полосы, позволяя выбрать читателю интересные публикации.

Что на самом деле представляет собой газетный заголовок? В польской лингвистической литературе часто приводится дефиниция В. Писарка, которая считается самой полной: «Nagłówek to wydrukowany tytuł (wraz z ewentualnymi nadtytułami i podtytułami) wypowiedzi, działu lub rubryki w czasopiśmie» (цит. за: Pałuszyńska 2006: 9).

Российская теория, посвященная газетным заголовкам, очень богата. Мы приведем довольно ёмкую и содержательную дефиницию А. А. Сафонова:

Заголовок в газете (...) - единица коммуникативная, он кратко информирует читателя о содержании газетного материала, осведомляет о значении, характере и степени важности событий, отразившихся на страницах газеты. По заголовку статьи , репортажа, фельетона, корреспонденции часто можно судить об отношении автора к описываемым событиям, о позиции редакции (Сафонов 1981: 205).

Обычно указывается на пять критериев эффективности заголовка: «он должен быть заметным, способным заинтересовать, эмоциональным, понят-

Как отмечает Ия Блюменталь «(...) в начале XIX века тексты в газетах печатались без заголовков. В начале сообщения или заметки обычно указывали лишь географический пункт - название города, откуда оно пришло, и дату его направления в редакцию» (Блюменталь 2013: 17). 
ным и конкретным» (Михейкина 2013: 79). Некоторые авторы указывают на усиление смысловой напряжённости газетного заголовка, который «приобретает необычную форму, становитс энергосберащую энергосберащую я оценочным, экспрессивным, рекламным; информирует, прогнозируя и настраивая на определённое восприятие газетного материала» ${ }^{2}$ (Покровская 2005: 70).

Газетный заголовок, как уже отмечалось, это «ярлык» статьи. Он должен привлечь внимание потенциального читателя и заставить его прочитать текст (хотя не секрет, что газету читают нередко только по заголовкам). Поэтому заголовок можно сравнить с рекламой продукта-текста, который его автор хочет «продать» читателю-«покупателю».

Одним из способов заинтересовать адресата является использование в газетном заголовке прецедентных текстов, точных или в трансформированном виде. Цель настоящей статьи - показать функционирование прецедентных текстов в газетных заголовках в изменённой, инновационной форме. Примером инновации послужит контаминация прецедентных текстов на примерах из российской и польской прессы.

Под контаминацией в настоящей статье мы понимаем объединение прецедентного текста со словом по принципу общей части контаминируемых элементов, т.н. «контаминационного узла» или объединение с «нулевым узлом», т.е. без общей части, прецедентного текста с другим словом (иначе - замена одного из компонентов текста другим словом). Мы сосредоточимся на семантике и прагматике новообразований без учёта структурных типов.

Сначала предстоит объяснить понятие «прецедентный текст». По мнению А. А. Ауловой,

термин «прецедентный текст» в научный обиход введён Ю. Н. Карауловым для обозначения общеизвестных цитат, имён, названий произведений, текстов песен, рекламы и др., имеющих сверхличностный характер и многократно возобновляющихся в дискурсе данной языковой личности (Аулова 2008: 161).

Очень важно отметить, что «текст становится прецедентным лишь в процессе коммуникации» (там же). Восприятие и понимание смысла прецедентного текста возможно тогда, когда читатель помнит данный текст. Он может сопоставить значение первоисточника с содержанием статьи и установить их тождество и различие. Поэтому можно сказать, что цитации в заголовках «являются объединяющим фактором, мостиком между адресатом и адресантом» (Покровская 2005: 71), «диалогом культурных единомышленников» (Басовская 2003: 57), поскольку они опираются «на общность универсальных - социальных, культурных или языковых - фоновых знаний автора и читателя» (Блюменталь 2013: 18).

Данные признаки отличают современный заголовок от «часто безликих, неинформативных, трафаретных заголовков тоталитарного периода» (Покровская 2005: 70). 
Прецедентные тексты соотносятся с понятием интертекстуальности, понимаемой как «сознательная цитатность, диалог между текстами и взаимодействие различных видов внутритекстовых дискурсов» (Сковородников 2004: 69). По словам М. В. Саблиной, «все тексты представляют собой интертексты, все они связаны между собой, любой текст строится как мозаика цитаций, любой текст есть продукт впитывания и трансформации какого-нибудь другого текста» (Саблина 2009: 94-95). Однако на первое место выдвигается интертекстуальность газетных заголовков. Обыгрывание в них широко понимаемой фразеологии, к которой причисляем и прецедентные тексты, является одним из признаков современного публицистического стиля.

Специфика использования заголовков такого типа в сегодняшних журналах заключается во всепроникающей ироничности цитирования. Даже в случае точного воспроизведения оригинального текста возникает комический эффект, который определяется противоречием цитируемого произведения и предметом журнальной статьи (Басовская 2003: 57).

Комический эффект и ироническое переосмысление классики ещё выразительнее в заголовках, представляющих собой изменённые цитаты, например в случае их контаминации, ср. Как разбиралась сталь 'об окончательном демонтаже узкоколейки в подмосковной Шатуре. Колейку разбирали бомжи в связи с тем, что закончилась её основная функция - перевоз торфа' (Московский Комсомолец 227/10/9) ${ }^{3}$ («Как закалялась сталь» 'автобиографический роман советского писателя Н. А. Островского. Название роману дала небольшая станция Боярка в Киевской области, а точнее трудности строительства Боярской узкоколейки в 20-е годы XX века. На строительстве узкоколейки «закалялась сталь характеров молодежи 20-х годов»' (http:// control.audiopedia.su/audio/15190) + разбираться в зн. 'демонтироваться'), Капитанская точка 'о волейболисте-ветеране сборной России - 36-летнем Сергее Тетюхине, который взял на себя обязанности капитана команды на Кубке мира по волейболу. На выбор Тетюхина повлияли его качества: сверхнадёжность и большая самоотдача’ (Российская газета 262/11/16) («Капuтанская дочка» 'историческая повесть А. С. Пушкина, посвященная событиям Крестьянской войны 1773-1775 гг. под предводительством Емельяна Пугачёва' + точный), Сдавай, страна огромная 'о предложении властей сдавать россиянами старую бытовую технику, а взамен приобретать новую, энергосберегающую’ (Огонёк 47/10/4) (сдавай + «Вставай страна огромная (вставай на смертный бой)» 'первая строчка российской патриотической

Как отмечает Ия Блюменталь «(...) в начале XIX века тексты в газетах печатались без заголовков. В начале сообщения или заметки обычно указывали лишь географический пункт - название города, откуда оно пришло, и дату его направления в редакцию» (Блюменталь 2013: 17). 
песни периода Великой Отечественной Войны, под заглавием «Священная война», ставшая своеобразным гимном защиты Отечества'), СТPAШНАЯ МММЕСТЬ 'о страшной мести обманутого в финансовой пирамиде МММ вкладчика, который в уличной драке зарезал одного из руководителей пирамиды' (Твой День 224/13/5) («Страшная месть» 'заглавие рассказа М. Гоголя из сборника «Вечера на хуторе близ Диканьки»' + $M M M$ 'финансовая пирамида'), Ból to jest nasz ostatni 'об умирании тяжелобольных в Польше от боли из-за убеждения, что морфин убивает’ (Nie 3/10/3) (ból + „Bój to jest nasz ostatni” 'фрагмент припева «Интернационала»'), Díunglo, ojczyzno moja 'о том, что индейцы из амазонских джунглей борются с правительством в Лиме и нефтепромышленниками за право на землю предков' (Newsweek 26/09/35) (dżunglo <джунгли> + „Litwo, ojczyzno moja” <Литва! О родина!> 'апострофа в поэме Адама Мицкевича «Пан Тадеуш»'), Cata wiedza w recce mas 'о Википедии, которая требует финансовой поддержки' (Wprost 1/12/68) (,,Cała władza w ręce rad” <вся власть Советам> "слова В. И. Ленина - лозунг Октябрьской революции' + wiedza <знания> + mas $<$ masa - толпа>), Krajobraz po pętli 'о состоянии польской партии «Самооборона» после смерти её лидера - Анджея Леппера, который повесился’ (Nie 32/12/6) (, Krajobraz po bitwie” <«Пейзаж после битвы»> ‘польский художественный фильм Анджея Вайды’ + pętli < pętla - петля>).

Как справедливо утверждает Е. Н. Басовская

Вольное обращение с классическими литературными текстами вряд ли заслуживает осуждения. В данном случае действует языковой закон, общий для всех типов устойчивых сочетаний слов: по мере фразеологизации связь выражения с первоисточником ослабляется, а значение целого перестаёт равняться сумме значений частей (Басовская 2003: 58).

Вышесказанное обозначает, что прецедентные тексты в газетных заголовках, а тем более их контаминированные версии, нередко десемантизируются. Они наделены совсем новым значением, о чем свидетельствуют приведенные выше примеры.

Бывают однако контаминации, которые включают одновременно структурную и семантическую контаминацию, т.е. в значении новообразования сложным образом переплетаются значения исходных компонентов, ср. $\boldsymbol{A}$ был ли деммальчик? 'о финансовом и политическом кризисе в России, причиной которого являются финансовые преступления. Кризис этот может поставить под сомнение существование демократии в стране' (http://www. aif.ru, 22.10.2008) (А был ли мальчик? 'ирон. было ли что-либо в действительности, на самом деле?; выражение сомнения в подлинности чего-либо'; генезис: повесть Максима Горького «Жизнь Клима Самгина» + демократия), Елена бесПРИКРАСная 'о бывшем министре сельского хозяйства Российской Федерации, обвиняемой в коррупции в большом масштабе. Это 
прекрасная и очень богатая женщина. Чтобы доказать свою невиновность она опровергает информацию о своем богатстве, фотографируясь без драгоценных украшений' (Аргументы и Факты 43/12/7) (Елена Прекрасная 'в древнегреческой мифологии прекраснейшая из женщин' + без прикрас), CEMEЙКА АДДАMC 'о том, что супруги из Америки, которые полгода назад усыновили двойню, подкинули ее в органы опеки Санкт-Петербурга' (Твой День 44/12/7) («Семейка Аддамс» 'заглавие американской чёрной комедии фэнтези о странной колдовской семье мазохистов, садистов и уродов' + ад), Мои шуниверситеты 'о том, что футбольный клуб «Динамо» сформировал личность знаменитого голкипера сборной России Антона Шунина' (Твой День 252/11/15) (Мои университеть 'о жизненном опыте, который сформировал личность, ее убеждения, принципы'; генезис: название автобиографической повести Максима Горького. Так писатель говорит о «школе жизни», которую он прошёл, работая у разных людей + Шунин 'фамилия футболиста'), Последний сбой-он трудный самый 'о неудаче в пуске межконтинентальной баллистической ракеты «Булава» с борта атомной подлодки «Дмитрий Донской». Во время пуска «Булавы» произошёл сбой. В результате ракета самоликвидировалась в воздухе и вместо долгожданного «зачёта» снова получила «незачёт»' (Московский Комсомолец 288/08/4) («Последний бой, он трудный самый» 'фрагмент припева военной песни' + сбой), Тела давно минувших дней 'о месте захоронения мировых коммунистических вождей, между прочим, Ленина, Мао Цзэдуна, Хо Ши Мина, Ким Ир Сена и др.' (Аргументы и Факты 43/11/18) (тела + дела давно минувших дней 'о делах, вещах, событиях, древних, почти забытых'; генезис: поэма Александра Пушкина «Руслан и Людмила»), Hulajze Jezuniu 'о раскошных ужинах перед Рождественским сочельником в государственных учреждениях в Польше' (Nie 1/09/15) (hulajże <кути> + ,Lulajże Jezuniu” 'заглавие одной из Рождественских колядок'), Kobiety na tramwaje, [bo pora w MPK złagodzić obyczaje] 'о женщинах, которые хотят стать вагоновожатыми' (Dziennik Łódzki 12/09/8) (Kobiety na traktory! 'один из лозунгов сталинской пропаганды 50-х годов XX века, рекламирующих модель женщины-ударницы, которая работает в разных отраслях промышленности, занимается общественной деятельностью' + tramwaje), Lenistwo macht frei 'о том, что поляки не могут привести в порядок территорию вокруг концентрационного лагеря Аушвиц-Биркенау в Освенциме с 1996 года' (Nie 8/11/9) (lenistwo <лень> + Arbeit macht frei 'фраза на немецком языке, которая в переводе означает «труд освобождает»'; генезис: Евангелие. Фраза была использована в 30-х годах XX века нацистской пропагандой в Германии для борьбы с безработицей; фраза в качестве лозунга была размещена на входе многих нацистских концентрационных лагерей, между прочим, лагеря Аушвиц-Биркенау'), Seks nocy letniej 'критически о комедии У. Шекспира «Сон в летнюю ночь», поставленной в Театре Атенеум в Варшаве. Главные обвинения это нагота ак- 
трис и эротика' (Polityka 6/12/73) (seks + „Sen nocy letniej” <«Сон в летнюю ночь»> 'комедия У. Шекспира').

Контаминированные прецедентные тексты в газетных заголовках дискредитируют первоисточник, который зачастую имеет возвышенный, патетический или трагический характер. С прагматической точки зрения они нередко имеют негативые коннотации, ср. Как разбиралась сталь, СТРАШНАЯ МММЕСТЬ, Елена бесПРИКРАСная, Последний сбой - он трудный самый, Тела давно минувших дней, Ból to jest nasz ostatni, Hulajże Jezuniu, Lenistwo macht frei, а также Много ЦУМа - и ничего... 'о самом большом универмаге в Москве (ЦУМ), который может разочаровать - в нем продавцов намного больше, чем потенциальных клиентов (посещающих) и «цены не просто кусаются, они практически лают»' (Аргументы и Факты 51/09/15) (много шума из ничего 'вокруг чего-либо незначительного, не стоящего внимания начался огромный ажиотаж’; генезис: название комедии У. Шекспира) + ЦУМа $+u)$, Пусть всегда будет сухо! 'о самых хороших подгузниках для детей' (Аргументы и Факты 13/10/32) (Пусть всегда будет солнце 'заглавие песни Аркадия Островского' + сухо), Пусть землячка вам будет пухом 'о «Кодексе обаятельной землячки», который должен помочь приезжим в Москву провинциалкам приобрести богатого мужа. «Олигархи, просто москвичи с квартирой, а особенно их мамы - берегитесь!» (Московский Комсомолец 226/10/3) (пусть земля вам будет пухом 'надгробная надпись, также фраза кончающая надгробную речь' + землячка), Hotd Tuski 'о платном объявлении - благодарности для польского премьер-министра Доналда Туска, какое на страницах «Газеты Выборчей» поместил президент города Гожув-Велькопольски. Стоимость объявления 97 тыс. зл.' (Nie 07/11/16) (Hołd Pruski < Прусская дань> 'вассальная присяга, принесённая польскому королю Сигизмунду Старому правителем Пруссии Альбрехтом Гогенцоллерном’+ Tuski/ Tusk 'фамилия польского премьер-министра'), Kot mit uns 'критически о биографии Папы Римского Бенедикта XVI, рассказанной его котом. Автор статьи считает такую биографию инфантильной, тем более, что кот считается богом человека, поскольку он выбрал человека своим другом' (Nie 49/08/9) (kot + Gott mit uns 'девиз, изображавшийся на гербе Германской империи, широко используемый в немецких войсках с XIX века, в частности, начертанный на пряжках ремня') и др.

Встречаются однако и одобрительные коннотации контаминированных прецедентных текстов, ср. Капитанская точка, Мои шуниверситеты, а также Пожсар-птица 'о героизме 15-летней ученицы из Хабаровска, которая спасла троих детей из пожара’ (http://www.rg.ru, 06.04.2010) (пожар + Жар-птица 'сказочная птица с ослепительно светящимися, сверкающими перьями'; перен. 'символ искомого счастья, объект вожделения, непостижимое совершенство'), Хождения Памука 'о нелёгком пути всемирно известного турецкого писателя, лауреата Нобелевской премии Орхана Па- 
мука (http://www.mk.ru, 31.08.2009) (хождение по мукам 'вереница тяжелых жизненных испытаний'; генезис: заглавие трилогии Алексея Толстого + Памука), Nieustraszeni lowcy gwiazd 'о любителях космоса, которые раз в год встречаются в местности Ёдлово, чтобы три дня наблюдать за небом в совершенно затемнённом помещении' (Wprost 2/12/76) (,Nieustraszeni towcy głów”' ‘заглавие песни рокового ансамбля «Леди Панк»' + gwiazd).

Прецедентные тексты это также обозначения известных имён. Их контаминации в газетных заголовках осмеивают первоисточник, деградируют его, придавая нередко иронический и неодобрительный оттенок, ср. ЖанКлод-Рамзан 'о визите голливудского актера Жан-Клод Ван Дамма в столицу Чечни - Грозный. Он принял участие в праздновании Дня города в Грозном, который совпал с днём рождения президента Чечни Рамзана Кадырова. ВанДамм называет Рамзана Кадырова своим другом. Кроме того актёр может сняться в фильме о Чечне: сценарий уже готов' (Московский Комсомолец 255/11/3) (Жан-Клод Ван Дамм + Рамзан [Кадыров]), Dominik Seks-Kahn 'о кандидате в президенты Франции - Доминике Стросс-Кане и его сексуальном скандале в нью-йоркской гостинице, а также о многих других сексуальных приключениях политика' (Polityka 51/11/54-55) (Dominik StraussKahn + seks), Hanna Gronkiewicz-Platz 'о споре из-за участка, на котором построили большое административное здание ДХ Вальди. Спор ведётся между инвестором здания, правительством Варшавы (президентом Ганной Гронкевич-Вальц) и наследниками участка земли под зданием. Наследники появились после постройки дорогого здания. Спор ведётся рядом со зданием Министерства юстиции, где стоит ДХ Вальди. О споре напоминает представительный паркинг перед Минюстом, закрытый, так как остаётся в пределах участка. Посетителям Минюста негде парковать, за что получают штрафы' (Nie 7/12/12) (Hanna Gronkiewicz-Waltz + Platz (pol. plac-участок), Lady Blaga 'о мистификациях в музыке поп, которые использует Леди Гага' (Polityka 9/12/72-74) (Lady Gaga + blaga <липа, выдумка, сочинительство>), Claudia Szofer 'прозвище польского автогонщика Христофора Холовчица, вероятно по поводу его внешнего вида, красноречивости и участия в рекламных роликах': [Pożegnanie z] Claudią Szofer 'о последнем, неудачном для автогонщика ралли Дакар, в котором он не победил из-за различных аварий' (Wprost 3/12/54) (Claudia Schiffer 'фамилия немецкой модели' + szofer <шофёр>).

В завершение необходимо отметить, что использование прецедентных текстов в газетных заголовках «нацелено на коммуникативное сотрудничество» (Аулова 2008: 166). Адресат должен понять и верно определить интенцию автора, а также воспринять закодированную информацию. Это считается довольно трудным, если прецедентный текст в газетном заголовке выступает в трансформированном виде ${ }^{4}$. Но, несмотря на форму прецедент-

Данные признаки отличают современный заголовок от «часто безликих, неинформативных, трафаретных заголовков тоталитарного периода» (Покровская 2005: 70). 
ного текста, исследователи справедливо замечают, что «многие прецеденты антонимичны для современного читателя, особенно молодого, а значит, не выполняют своей роли» (там же), что означает «минус эффект коммуникации» (там же). Это касается, прежде всего, классиков литературы, а также песен, фильмов. Учитывая эту тенденцию, авторы часто черпают прецедентный материал из массовой культуры, о чём отчасти свидетельствуют рассмотренные в данной статье контаминированные прецедентные тексты.

\section{Библиография}

Аулова А. А. (2008), Взаимодействие заголовка и медиатекста через преиедентный феномен, [в:] ред. М. Ю. Казак, У. Перси, А. В. Полонский, Е. А. Кожемякин, Журналистика и медиаобразование-2008. Сборник трудов III Международной научно-практической конферениии, т. II, Белгород, с. 159-166.

Басовская Е. Н. (2003), Обезглавливание через озаглавливание, «Русская речь», № 4, с. 56-62.

Блюменталь И. (2013), О культурнознаковых прецедентных высказываниях в заголовках (по материалам еженедельника «Огонек» за 2012 год), „Acta Universitatis Lodziensis. Folia Linguistica Rossica", z. 9: Aktualne problemy semantyki i pragmatyki, red. A. Piasecka, s. $17-26$.

Михейкина С. Г. (2013), Каламбурных дел мастера, «Русская речь», № 1, с. 79-81.

Покровская Е. В. (2005), Газета в современной культурно-речевой ситуачии, «Русская речь», № 5 , c. $69-74$.

Саблина М. В. (2009), Интертекстуальность заголовков современной российской прессы, http://elib.sfu-kras.ru/bitstream/2311/1570/1/10_sablina.pdf.

Сафонов А. А. (1981), Стилистика газетных заголовков, [в:] ред. Д. Э. Розенталь, Стилистика газетных жанров, Москва, с. 205-228.

Свистельникова С. А. (2008), Воздействующуая функция заголовка газетной статьи, [в:] ред. М. Ю. Казак, У. Перси, А. В. Полонский, Е. А. Кожемякин, Журналистика и медиаобразование-2008. Сборник трудов III Международной научно-практической конференции, т. II, Белгород, с. 166-170.

Сковородников А. П. (2004), Рефлексы постмодернистской стилистики в языке российских газет, «Русская речь», № 6, с. 68-76.

Gajda S. (1987), Społeczne determinacje nazw własnych tekstów (tytułów), „Socjolingwistyka”, z. 6, red. W. Lubaś, s. 79-89.

Pałuszyńska E. (2006), Nagłówki w „Gazecie Wyborczej” (ekspresywna leksyka, frazematyka, metaforyka), Łódź. 
Krystyna Ratajczyk

\section{Contaminated Precedent Texts in Headlines - as a Feature of the Contemporary Press Style (semantics and pragmatics)}

\section{Summary}

The article is devoted to the phenomenon of contamination in precedent texts. The objects of this research are precedent texts in headlines. The article shows the comical effect and irony of contaminated precedent texts. Texts of that kind are discrediting the original text. 